\title{
MOTIVATION OF STUDENTS OF ECONOMIC AND TECHNICAL STUDY PROGRAMMES AS A TOOL OF COMPETITIVENESS OF UNIVERSITIES AND COLLEGES: EMPIRICAL STUDY
}

\author{
Kateřina Berková ${ }^{\bowtie}$, Jana Borůvková2, Lenka Lízalová \\ ${ }^{凶 1}$ College of Polytechnics Jihlava, Jihlava, Czech Republic, katerina.berkova@vspj.cz \\ ${ }^{2}$ College of Polytechnics Jihlava, Jihlava, Czech Republic \\ Highlights \\ - The increase of students' motivation proves to be essential for the competitiveness of universities \\ - $\quad$ Students are the most significantly motivated by experience-focused learning \\ - $\quad$ Students of the technical study programmes assess the motivation factors more strictly
}

\section{Abstract}

The article presents an analysis of factors influencing the students' motivation to study economic subjects in economic and technical study programmes in the conditions of a practically oriented college. The research is focused on quality management systems of universities and the competitiveness in the tertiary education market. Specifically, the area of quality of higher education is addressed, through students' assessment of the subject of Business Administration. Motivation factors related to teaching techniques were classified and the intensity of motivation of the respondents was investigated in the questionnaire survey. The statistical analysis of data suggests that there are differences in the motivation of students of economic and technical study programmes. Students of technical study programmes Applied Computer Science are more demanding and have higher expectations from study programmes compared to students in the study programmes of Finance and Management, whose expectations are lower. The results are discussed and compared with a similar foreign research. A pedagogical constructivism should be introduced into the Czech education, resulting in enhancement of attractiveness of the study programmes, thus increasing the level of competitiveness of the college.

\section{Keywords}

Motivation of students, economics, technics, universities' competitiveness, colleges' competitiveness

Berková K., Borůvková J., Lízalová L. (2018) "Motivation of Students of Economic and Technical Study Programmes as a Tool of Competitiveness of Universities and Colleges: Empirical Study", Journal on Efficiency and Responsibility in Education and Science, Vol. 11, No. 4, pp. 72-77, online ISSN 1803-1617, printed ISSN 2336-2375, doi: 10.7160/eriesj.2018.110401.

\section{Introduction}

Competitiveness of universities represents a reflection of the quality of each individual institution, which is based on its internal evaluation. Nowadays, the quality has become one of the competitiveness tools on the market of tertiary education. Different approaches are used in the Czech Republic - universities primarily utilise models that have become wellestablished commercially or on the European level such as Common assessment framework (CAF) and the European foundation for quality management (EFQM). Furthermore, they use the Total quality management (TQM) model, which is based on the principle of positive motivation and focuses on the quality of stakeholders and all resources; in addition, ISO certification of 9000 series is used (Krpálková Krelová, 2014; Mulač and Mulačová, 2014). Measurements of quality and evaluation are also possible through assessment of teaching programmes, i.e. through students who co-participate in the evaluation process (Mulač and Mulačová, 2014).

Currently, the universities have been experiencing a decrease in the number of students, to which they attempt to respond using various tools, in accordance with the strategic objectives and quality assurance systems implemented by universities. One of the target tools is monitoring and reinforcement of the motivational potential, i.e. increasing of the attractiveness of the study programme, which increases the potential of obtaining students. This increases competitiveness in the market of tertiary education. As mentioned above, the problem is addressed by, for example, Savenkova and Olesina (2018) or Kim and Regh (2018). The study-oriented motivation of students has become increasingly significant and, considering the conditions of decreasing numbers of students in the Czech Republic, it becomes one of the predominant tools of competitiveness at universities. The above-mentioned facts prove that the matter of study-oriented motivation of students is a rather essential variable in the quality assurance system at universities.

Motivation plays a significant role in the branch of education. Fontana (2014: 153) claims that motivation is one of the fundamental effects which determines the efficiency of the educational process. There is, however, a high number of factors that affects the intensity of motivation. In general, they comprise mainly the teacher's effect on students, i.e. his/ her professional as well as overall competence profile (Pasiar et al, 2015). Nevertheless, it is not possible to disregard the content of the study programme as such (the subject or the whole branch), self-strictness of students and their expectations regarded to the study programme (Berková, Novák and Pasiar, 2018). Expectations of individual persons and their fulfilment may be regarded as an important factor shaping the level of intensity of motivation. This fact results from the classification of motivation, which is defined as a summary of strong suites that organize the behaviour and experience of an individual with the objective of changing the existing unsatisfactory situation or achieving something positive (Plháková, 2003: 319).

In the present world of technological progress, which allows for a different manner of education - in a more interactive format - it is increasingly difficult to attract students and motivate them to learn. Students may find information themselves and quite easily as it is accessible through modern resources. It is essential to ensure that the teacher is motivated to maintain the development of his/her professional and pedagogical competences. The aforementioned motivation is reflected in an 
increased level of students' motivation (Stranovská, Lalinská and Boboňová, 2018). Findik-Coskuncay, Alkis and OzkanYildirim (2018), publish a relatively new research focused on management systems of the quality of learning of 470 university students through improvements in e-learning services.

The objective of this study is to determine factors that affect behaviour in the area of tertiary education and learning management systems. The proposed constructional model was verified on the basis of modelling of structural equations. Using these methods, it was determined that students perceive e-learning positively as regards its efficiency, ease of use, pleasure and satisfaction with the interactive environment. Furthermore, they made a positive evaluation of the feedback which e-learning provides throughout the study programme. Interactive education has become a widespread format of the process of teaching and learning. This element implemented through modern technologies, communication technologies, allows for real-time education based on interaction. It further increases the learning-oriented motivation of students, may increase the active participation of students and positively influence the process of learning in the branch of tertiary education (Tan et al, 2018). E-learning, considering its sophistication and complexity, represents an educational platform suitable for the university environment (Ogrodzka-Mazur et al, 2017). It allows for the development of higher cognitive processes such as analysis, evaluation and creativity, which require an extensive interaction and collaboration between students and facilitators (Lau et al, 2018).

Currently, the role of students is gradually transforming into the role of clients of universities in the Czech Republic. Therefore, students no longer value their education and services provided to them by universities. This fact results, inter alia, from a demographical decrease which is currently reflected in tertiary education. The breakpoint occurred in 2012-2014, while around 2023-2025 the demographic curve is expected to be increasing in tertiary education once again (Koucký and Bartušek, 2011). The decrease of the number of students might (even unintentionally) cause decreases in the quality of the educational process, which represents one of the variables of quality monitoring at universities. Mulač and Mulačová (2014) stipulate that financial allocations to individual universities are based on their quality. The aforementioned fact is also confirmed in the study drafted by Šipikal and Némethová (2017: 170), who address the matter of financing of universities on the basis of their performance. They emphasise the importance of objectives of public policies - increasing the participation of universities in education, international interaction and cooperation with the practice, etc., which should be reflected in the calculation of the performance of each respective university.

The content of education reflecting trends from the practical application of economics as well as modern means and teaching methods are definitely the factors which increase attractiveness of a study branch, respectively individual subjects. This also leads to an increase in the motivational potential of the study programme. Nevertheless, it is to be mentioned that students' motivation is significantly determined by their teacher's personality. The level of the teacher's pedagogical competences is based on the qualifications, scope, form and quality of practical skills, specialisations, age, professional experience, verbal competences and attitudes (Windham, 1988). An ideal teacher features resistance, adaptability, ability to absorb new knowledge, social empathy and communication skills (Dytrtová and Krhutová, 2009: 15). A suitable form of teaching has positive effects on education. Students featuring insufficient levels of motivation are not interested in the course of solving of the respective subject, they are not concerned about mistakes which they make or correct procedures; they are only interested in the final result of the task (Boekaerts, 2004). The research of Berková and Krejčová (2016), which inspired the abovementioned new research, shows that students perceive expert knowledge of the teacher as the most significant motivational factor.

Considering the fact that the applied teaching methods and style of pedagogical work of the teacher as well as the teacher's motivation and professional competences affect students' motivation(Brožová, Horáková and Fiedler, 2018), the respective matter was continuously solved within the scope of a systematic research lasting several years. In their research, the authors (Berková, Králová and Krejčová, 2017; Berková and Krejčová, 2016; Krejčová and Berková, 2016) dealt with the matter of utilisation of modern teaching methods, i.e. experience-focused learning and teaching on the basis of pedagogical constructivism in the study programmes of economics. The most commonly used methods are the discussion methods followed by methods of problem-focused learning such as problem-oriented questions; case study methods prove to be on a significant level as well. In conclusion, the authors state that in the Czech environment modern methods are still not as commonly used as abroad. Nowadays, teaching on the basis of interactive environments utilise information technologies prove to be rather neglected. In addition, one of the topics which are currently discussed is the type of teachers which should be trained for the new generations of students, and which subjects should be implemented with the objective of reinforcement of students' motivation as regards learning and obtaining general competences (Zygaitiene and Buivydaite, 2017, compared to $\mathrm{Au}, 2011$ ).

\section{Research Problem and Objective}

The research is focused on reviewing the factors which affect students' motivation to study the subject Economics. Specifically in case of students studying economic and technical study programmes in conditions of a non-university type of the College of Polytechnics Jihlava, Czech Republic. This is a primary research, as the research sample will be extended to other relevant college students prospectively. The results will be further used to experimentally measure the effects of experiential methods on professional competence. Considering the fact that students of the study programmes Finance and Management and Applied Computer Science study the subject Economics together, the present study is focused on the motivation of students in relation to studying of this subject. The motivation factors are related solely to the teaching level and a comparison of the intensity of motivation between the branches is presented. Another objective of the study pertains to the determination of factors which students assess similarly and those which they assess completely differently, separately for students of Finance and Management and also separately for students of Applied Computer Science. The subject of the research is the research hypothesis that the perception of motivation factors by students of economic and technical study programmes in connection with studying of the subject Economics is different between the study programmes as well as inside each of the study programmes. This research was prompted by the current decrease in the number of students in tertiary education; its contribution is in the final recommendation drafted on the basis of an empirical analysis. The article presents inspiring tools for the increase of students' interest in studying economics. 


\section{Materials and Methods}

The research was conducted concurrently for both study programmes, within the scope of teaching in the term of February-March 2018. Students of the first year of Finance and Management $(n=52)$ and students for the first and second year of Applied Computer Science $(n=30)$ at the College of Polytechnics Jihlava in the Czech Republic, a non-university type of school, participated in the research. In total, the research sample comprised 82 respondents, the selection of whom was intentional. The principal criterion of selection was a comparison of the intensity of motivation of students studying economic and technical study programmes as regards studying of the subject of Corporate Economy immediately after its completion, in conditions of a non-university type of college. Considering the fact that the students had completed the aforementioned subject in the preceding winter semester of $2017 / 2018$, it was desirable to include them in the selection.

The factors in case of which the students assessed motivational effects were divided into three sets; each category comprised three selections:

1. Form of elaboration of the educational content (F1 Implications of the teaching materials; F2 Reference examples for preparation for credit test/examinations; F3 PowerPoint presentations, e-learning support, professional literature without extensive relevance);

2. Maintaining of students' attention in class (F4 Discussion, questions during the lecture and time for enquiries; F5 Stories from the practice, case studies and solving of problems from the practice; F6 Independent work of the students related to a task and the teacher's corrections);

3. Style of explanation of lessons (F7 Teacher's guidance how to think - analogies, critical analysis and evaluation of information; F8 Acceptance of less frequent ideas presented by students and analysis of mistakes; F9 Teacher presents more than just facts, the student is able to coordinate their cognitive resources, emotions and actions in relation to learning goals, the student acquires metacognitive experience, realizes his own cognitive ability).

Selection of the factors was inspired by a long-term research conducted in 2015-2017 which was focused on the motivation of students at secondary schools of economics, in relation to studying of economic subjects (Pasiar et al, 2015; Berková and Krejčová, 2016; Berková et al, 2018). These factors were also chosen for the purpose of comparing the results of motivational perception of the factors by students of secondary and tertiary education as regards future development of solving of the research task. Furthermore, they were selected considering the primary objective of our research, i.e. ensuring motivation of students of economic and technical study programmes in conditions of a non-university type of college, with the principal focus being placed on the level of teaching (teacher's lectures) and students' learning.

Collection of data was performed using a questionnaire which was drafted in the online e-learning environment of Moodle. The structure of the questionnaire was identical for both reviewed study programmes. The questionnaire contained 2 questions determining factual data (gender and study programmes) as well as 9 factors in case of which the students were to evaluate the intensity of motivational potential on the scale between - to 2. (The lowest levels of intensity of motivational potential, i.e. -2 and -1 , represent a demotivating effect of the factors while the highest levels of intensity of motivational potential, i.e. the values of 1 and 2, represent a motivating effect of the factors; the value of 0 represents the respective student's indifferent relation to the factor.)

The non-parametric Mann-Whitney $U$ test was used. Selection of non-parametric statistics proves to be justifiable considering the values of compared variables. They represent numeric, ordinal variables which comprise max. 5 categories on the scale between -2 and 2. Furthermore, correlation coefficients were calculated for all pairs of motivation factors, with the objective of determining which factors students evaluate similarly and which factors students evaluate completely differently - once again separately for students of Finance and Management and students of Applied Computer Science. Kendall's tau-b was selected from the high number of existing correlation coefficients as the analysed variables were ordinal and featured the same scale. The respective coefficient ranges between -1 and +1 . If it approximates zero (it is not statistically significant), the factors are independent - students evaluate the factors independently (differently).

Null (statistical) hypotheses, which form the subject matter of verification on the 5\% level of significance, are following:

$H_{0-1}:$ Mean values of the motivation factor are identical in both study programmes.

$H_{0-2}:$ Students of Finance and Management evaluate all the motivation factors identically.

$H_{0-3}:$ Students of Applied Computer Science evaluate all the motivation factors identically.

\section{Results}

\section{Comparison of Motivation Factors}

The resulting order of factors for Finance and Management (FM) $n=52$ and Applied Computer Science (ACS) $n=30$ is presented in Table 1.

\begin{tabular}{|l|c|c|c|c|}
\hline \multirow{2}{*}{ Motivation Factors } & \multicolumn{2}{c|}{ Mean } & \multicolumn{2}{c|}{ Median } \\
\cline { 2 - 5 } & FM & ACS & FM & ACS \\
\hline Examples and stories from the practice & 1.31 & 1.33 & 1.50 & 1.00 \\
\hline Teacher presents more than just facts & 1.19 & 0.97 & 1.00 & 1.00 \\
\hline Implications of teaching materials & 1.15 & 1.13 & 1.00 & 1.00 \\
\hline $\begin{array}{l}\text { Analysis of mistakes, acceptance of less } \\
\text { frequent ideas }\end{array}$ & 1.12 & 1.37 & 1.00 & 1.50 \\
\hline Teacher's guidance on how to think & 1.13 & 0.90 & 1.00 & 1.00 \\
\hline $\begin{array}{l}\text { Questions, discussion, enquiries during } \\
\text { lecture }\end{array}$ & 0.54 & 0.73 & 1.00 & 1.00 \\
\hline $\begin{array}{l}\text { Reference examples for exams, without } \\
\text { practice }\end{array}$ & 0.37 & -0.13 & 1.00 & 1.00 \\
\hline PPT presentations, e-learning, books & 0.02 & -0.47 & 0.00 & 0.00 \\
\hline Independent work in lessons & -0.12 & -0.97 & 0.00 & 0.00 \\
\hline
\end{tabular}

Table 1: Descriptive Statistics: Motivation Factors in the Study Programmes of Finance and Management, and Applied Computer Science, 2018 (source: own calculation)

The scope of significant factors for students of Finance and Management comprises - considering the determined mean values - any and all factors from the category of Form of elaboration of the educational content. This category consists of following factors from table 1: Teacher's guidance on how to think; Analysis of mistakes, acceptance of less frequent ideas; Teacher presents more than just facts. This last factor means that the student is able to coordinate their cognitive resources, emotions and actions in relation to learning goals, the student acquires metacognitive experience, realizes his own cognitive ability. The examples and stories from the practice and solving of problems are also included in the category of Form of elaboration of the educational content. This factor corresponds to the factor of Implications of teaching materials. The intensity of the aforementioned factors exceeds the value of 1 . 
In addition, the results clearly show that students feel demotivating effects of independent work in lessons in case of which the teacher solely reviews the correctness of their solutions without any in-depth connotations or discussions. This is also related to the fact that e-learning support, PowerPoint presentations and professional literature are not motivating for students either, respectively they are indifferent to this factor. If such materials were not available, their motivation related to studying economic subjects would not be affected. The motivation factor of Questions and enquiries during lecture, in case of which the value is higher (0.54), may be interpreted similarly. Current generation of students in the first year of Finance and Management is most motivated by examples and stories from the practice, on which it is essential to focus more closely, thus focusing on problem-solving tasks featuring attractive elements.

Students of Applied Computer Science assess the reviewed factors more critically and strictly than students of Finance and Management. This fact is the most obvious in case of the factors of Reference examples for exams, without practice; PPT presentations, e-learning, books; and Independent work in lessons. The mean values representing the intensity of the motivational effects are negative, i.e. these factors are demotivating for the students - unlike the indifferent relation to these factors determined in case of students or Finance and Management. Students of Applied Computer Science would be most motivated by Stories and examples from the practice; Analysis of mistakes, acceptance of less frequent ideas; and Implications of teaching materials. In case of students of Finance and Management, the value of 1 was exceeded for more factors than in case of students of Applied Computer Science. In addition, students of the economic study programmes used negative values for fewer factors. This fact suggests that technical students of a practically oriented college have higher expectations from their college study programme as well as higher requirements related to the study programme. They are not satisfied with superficial knowledge.

\section{Interdisciplinary Differences Related to Perception of the Motivation Factors}

Table 2 presents $p$-values for all the motivation factors.

\begin{tabular}{|l|c|}
\hline \multicolumn{1}{|c|}{ Motivation Factors } & $\boldsymbol{p}$-value \\
\hline Implications of teaching materials & 0.648 \\
\hline Reference examples for exams, without practice & 0.059 \\
\hline PPT presentations, e-learning, books & 0.080 \\
\hline Questions, discussion, enquiries during lecture & 0.425 \\
\hline Examples and stories from the practice & 0.662 \\
\hline Independent work in lessons & 0.002 \\
\hline Teacher's guidance on how to think & 0.308 \\
\hline Analysis of mistakes, acceptance of less frequent ideas & 0.107 \\
\hline Teacher presents more than just facts & 0.356 \\
\hline
\end{tabular}

Table 2: $\boldsymbol{P}$-values of Mann-Whitney Test - Comparison of Interdisciplinary Differences, 2018 (source: own calculation)

At the 5\% level of significance, we reject the null hypothesis $\mathbf{H}_{0-1}$ solely in case of the factors of Independent work in lessons and Teacher's corrections of solutions.

The reviewed study programmes prove to differ only in case of the respective factor, whereas students of Applied Computer Science assess this factor more strictly and it is more demotivating for them than for students of Finance and Management. The other motivation factors do not feature statistically significantly different medians for the study programmes. It is to be emphasized that even though a statistically significant difference had not been proven, the study programmes show only minor differences in case of the following factors: Reference examples for exams/credit test, without practice; and Studying using e-learning support, books and PowerPoint presentations. The values of the above-mentioned factors are negative in case of students of Applied Computer Science while being positive in case of students of the economic study programmes (Table 1). On the basis of this fact it may be deduced that students of the technical study programmes are demotivated by these means while students of the economic study programmes prove to be indifferent to these factors, i.e. students of technical subjects appreciate analyses of procedures leading to solutions of each respective problem more than obtaining solely the final solution to the task (compare to Boekaerts, 2004).

\section{Kendall's tau-b Correlation Coefficients - Pairs of Motivation Factors}

The following pairs of motivation factors with a positive dependence have been determined on the $5 \%$ level of significance (students of Finance and Management perceive these pairs of factors similarly):

- F1 Implications of the teaching materials in combination with Discussion and questions during lectures (0.321); Teacher's guidance on how to think on the basis of analogies and critical analyses (0.258); Acceptance of less frequent ideas and analysis of mistakes (0.362); and Teacher's ability to present more than just facts $(0.236)$;

- F2 Reference examples for credit test/exam in combination with PowerPoint presentations, e-learning support and professional books (0.404); and Teacher's ability to present more than just facts $(0.226)$;

- F3 PowerPoint presentations, e-learning support and professional books in combination with Teacher's ability to present more than just facts (0.273);

- F4 Discussion and questions during lessons in combination with Stories and case studies from practice (0.252);

- $\quad$ F5 Stories and examples from practice in combination with Teacher's guidance how to think - analogies, critical analyses and evaluation of information (0.333); and Acceptance of less frequent ideas and analysis of mistakes (0.400);

- $\quad$ F6 Students' independent work on a given task and the teacher's corrections in combination with Teacher's guidance on how to think - analogies, critical analyses and evaluation of information (0.236).

At the 5\% level of significance, we do not reject the null hypothesis $\mathrm{H}_{0-2}$ for the motivation factors.

The results document the fact that students of Finance and Management prove to evaluate similarly primarily factors within the same category, which might result from interconnections between them. They also perform similar evaluations of factors in case of which they might perceive similar purposes for use in the teaching process, even though they are from different categories. For example, Stories from practice; and Teacher's guidance how to think; respectively Discussion during lessons, in case of which it is obvious that real stories from practice invoke thinking and the teacher has to lead students to the manner in which they are supposed to solve each respective problem, which also requires discussion during the teaching process. In addition, it is possible to mention, for example, 
Stories from practice; and Acceptance of less frequent ideas and analysis of mistakes. Once again, in case of Stories and examples from practice, which prove to be focused on problems, the aforementioned manner of analysis of mistakes and acceptance of less frequent ideas of students is highly adequate. Therefore, students might perceive their motivation potential. However, the similar evaluation of the factors of Students' independent work on a given task; and Teacher's guidance how to think proves to be rather inconsistent with the above-mentioned results.

The evaluations presented by students of Applied Computer Science are stricter. It may even be claimed that the factors of Reference examples for preparation for credit test/exams, without practice; and Independent work in lessons have negative effects and teaching performed using these manners would not meet their expectations - in comparison with the students of Finance and Management. The latter students, on the contrary, evaluate these factors positively, even though the intensity of motivation proves to be lower. However, students of Applied Computer Science feature a similar approach to the importance of teaching materials comprising acceptance of less frequent ideas and analyses of mistakes; stories from the practice comprising acceptance of less frequent ideas as well as their teacher's guidance on how to think, with the teacher's property of presenting more than just facts.

Students evaluate differently the following two factors:

- F2 Reference examples for credit test/exam and F4 Discussion and questions during lessons $(-0.217)$;

- F2 Reference examples for credit test/exam and F7 Teacher's guidance how to think

- $(-0.260)$

- F4 Discussion and questions during lessons and F6 Students' independent work on a given task and the teacher's corrections $(-0.271)$;

- $\quad$ F5 Stories and examples from practice and F9 Teacher presents more than just facts $(-0.345)$.

At the 5\% level of significance, we reject the null hypothesis $\mathrm{H}_{0-3}$ for the factors F2xF4, F2xF7, F4xF6 and F5xF9.

\section{Discussion}

The research focused on the motivation of students in conditions of a practically oriented college confirmed the hypothesis that perception of motivation factors by students of economic and technical study programmes in relation to studying of economic subjects proves to be different on both the interdisciplinary level as well as within the scope of each study programmes as such. It resulted in determining of several fundamental facts which are to be approached materially while interpreting the respective relations with a certain amount of reservations.

As regards students of Finance and Management as well as students of Applied Computer Science, the significant factors which motivate them to study economic subjects include (a) Teacher's guidance on how to think; (b) Acceptance of less frequent ideas; and (c) Analysis of mistakes and Teacher presents more than just facts from the category of Manner of explanation of lessons. In addition, the scope comprised Examples and stories from the practice; and Looking for solutions to problems from the category of Maintaining students'attention in class. In order to prepare such stories, it is essential to utilise interdisciplinarity of individual subjects, interconnect individual findings and respect interdisciplinary relations between related disciplines on the level of subjects or topics (Kim and Regh, 2018; Savenkova and Olesina, 2018). Such principles, on the basis of which the teaching should be based (according to students), correspond to the nature and philosophy of experience-focused learning; however, this trend has not become so widespread in tertiary education yet (Berková, Novák and Pasiar, 2018). Nevertheless, it proves to be desirable - based on the students' requirements and expectations.

Students of the economic study programmes regard independent work during the teaching process, in case of which the teacher solely checks and corrects solutions without any in-depth connotations, as a demotivating factor. An indifferent relation was determined in case of the variables of discussion and studying based on e-learning support, PowerPoint presentations and professional books. The determined findings are, however, inconsistent with several recent foreign research papers which, on the contrary, prove attractiveness of e-learning being the interactive form of education (Findik-Coskuncay, Alkis and Ozkan-Yildirim, 2018; Lau et al, 2018; Tan et al, 2018). Students might regard these factors as demotivating because they require something else than their common experience at school. They require that the education should be more based on dialogue and, possibly, even more interactive. This means that e-learning support might not utilise its full potential while duplicating the standard, traditional text-based materials without any interactive elements or feedback.

Students of the technical study programmes (Applied Computer Science) assess the reviewed factors more strictly (critically), as determined in case of Reference examples for exams, without practice; Studying based on e-learning support, books and PowerPoint presentations; and Independent work in lessons (comp. Findik-Coskuncay, Alkis and Ozkan-Yildirim, 2018; Lau et al, 2018; Tan et al, 2018). These factors prove to feature highly demotivating effects on this group of students.

It may be stated that significance of the factors proves to be assessed by students similarly within the scope of each reviewed study programmes of study, even though certain inconsistencies were determined as regards evaluation of the factors of Independent work in lessons and Teacher's guidance on how to think. It is rather interesting that students jointly compared teacher's guidance on how to think with the principles of experience-focused learning, i.e. on the basis of real stories and active learning. However, they also evaluated it similarly to the principles of traditional teaching without any attractive elements. The above-mentioned discrepancy might be explained by, for example, the fact that students perceive and interpret teacher's guidance on how to think differently. They might regard this activity as sole explanations of the study materials, respectively they are not led to becoming familiar with the significance of information during the thinking process (comp. Berková et al, 2018; Berková and Krejčová, 2016).

As mentioned above, the findings suggest possible manners of increasing the quality of education in accordance with the strategic objectives and quality assurance systems applicable to university education as well as support of acquiring students, as documented by certain national and international studies (Kim and Regh, 2018; Savenkova and Olesina, 2018; Mulač and Mulačová, 2014).

\section{Conclusion}

The objective of this study was to review the motivation factors applicable to students of economic and technical study programmes in relation to studying of economic subjects in conditions of a practically oriented college. Therefore, we emphasized the directions allowing for improvements in competitiveness on the market of tertiary education, in the area of improvement of quality of the educational process. 
The present research determined that it is generally simpler to motivate students of technical study programmes in conditions of a practically oriented college since these students are really interested in their study programmes. Students of technical study programmes are more demanding and have higher expectations related to their study programme - in comparison with students of an economic study programmes (Finance and Management) whose expectations are lower. Therefore, it may be assumed that a teacher's motivational influence on a group of students of

economic study programmes is a more complicated issue.

In spite of the above-mentioned principal differences in motivation of students of economic and technical study programmes at a practically oriented college, it may be stated that both groups would be most motivated by the so-called experience-focused learning based on an active problem-solving process in the form of live stories comprising a subsequent analysis of mistakes and guidelines for reviewing the respective problem. In order to maintain quality, it is desirable to include checks on the implementation of learning strategies in the form of evaluation tools. Although it is a primary research that has been placed in the conditions of a practically oriented college, in the area of increasing the motivation potential of economic subjects, the authors consider these recommendations in the university environment to be up to date. Teaching should be based more on experience. The authors will prospectively extend the research sample to other relevant college students. Further, authors plan to experimentally measure the effects of experiential methods on the development of professional competencies desirable in the labour market.

\section{Acknowledgements}

This research was supported by the College of Polytechnics, Jihlava, Czech under Grant No. 1170/4/181 "Model of Permeability of Corporate Economy and Financial Accounting in the Quality Improving System of the College of Polytechnics Jihlava".

\section{References}

Berková, K., Novák, J. and Pasiar, L. (2018) Modernizace ekonomického vzdělávání $\mathrm{v}$ kontextu taxonomií výukových cílů, Prostějov: Computer Media.

Berková, K., Králová, A. and Krejčová, K. (2017) 'Application of the metacognitive strategy in economic education in the Czech Republic', Turkish Online Journal of Educational Technology, Special Issue for INTE 2017, pp. 373-380.

Berková, K. and Krejčová, K. (2016) 'Effect of teachers' abilities on students' motivation with varying levels of intellectual abilities in the economics', Journal on Efficiency and Responsibility in Education and Science, Vol. 9, No. 3, pp. 81-87. https://doi.org/10.7160/eriesj.2016.090304

Boekaerts, M. (2004) Motivation to learn, Geneva: International Bureau of Education.

Brožová, H., Horáková, J. and Fiedler, J. (2018) 'Lecturers' managerial competencies important for students at the Czech university of life sciences', Problems of Education in the 21st Century, Vol. 76, No. 4, pp. 465-482.

Dytrtová, R. and Krhutová, M. (2009) Učitel. Příprava na profesi, Prague: Grada.

Findik-Coskuncay, D., Alkis, N. and Ozkan-Yildirim, S. (2018) 'A structural model for students' adoption of learning management systems: An empirical investigation in the higher education context', Educational Technology \& Society, Vol. 21, No. 2, pp. 13-27.
Fontana, D. (2014) Psychologie ve školní praxi, Prague: Portál. Kim, H. and Rehg, M. (2018) 'Faculty performance and morale in higher education: A systems approach', Systems Research and Behavioral Science, Vol. 35, No. 3, pp. 308-323. http://dx.doi. org/10.1002/sres.2495

Krejčová, K. and Berková, K. (2016) 'Abilities of Economic Subjects' Teachers and Their Impact on Students' Motivation', Proceedings of the 13th International Conference Efficiency and Responsibility in Education 2016, Prague, pp. 286-292.

Koucký, J. and Bartušek, J. (2011) Demografický vývoj a projekce výkonů vysokých škol, Prague: Univerzita Karlova v Praze.

Krpálková Krelová, K. (2014) 'Quality management systems in economic education and school enrollment rates as a parameter of quality school', Integration of Economic Education, Prague, pp. 106-111.

Lau, K.H., Lam, T., Kam, B.H., Nkhoma, M., Richardson, J. and Thomas, S. (2018) 'The role of textbook learning resources in e-learning: A taxonomic study', Computers \& Education, Vol. 118, pp. 10-24. http://dx.doi.org/10.1016/j. compedu.2017.11.005

Mulač, P. and Mulačová, V. (2014) 'Výsledky dotazníkového šetření k řízení kvality českých neuniverzitních vysokých škol', Proceedings of the 6th International Conference Competition, Jihlava, pp. 165-173.

Ogrodzka-Mazur, E., Szafrańska, A., Malach, J. and Chmura, M. (2017) 'The Use of E-learning Resources by Academic Teachers - a Polish- Czech Comparative Study', The New Educational Review, Vol. 50, No. 4, pp. 169-185. http://dx.doi.org/10.15804/ tner.2017.50.4.14

Pasiar, L., Berková, K., Krejčová, K., Pavera, L., Čonková, A. and Chmelárová, Z. (2015) Osobnost' učitel'a v ekonomickom vzdelávaní, Bratislava: EKONÓM.

Plháková, A. (2003) Učebnice obecné psychologie, Prague: Academia.

Savenkova, L.G. and Olesina, E.P. (2018) 'Strategic planning as a factor of improvement of contemporary education quality management', Quality - Access to Success, Vol. 19, No. 164, pp. 82-87.

Stranovská, E., Lalinská, M. and Boboňová, I. (2018) 'Teachers motivation towards assessment of their professional competences', Problems of Education in the 21st Century, Vol. 76, No. 4, pp. 561-574.

Šipikal, M. and Némethová, V. (2017) 'Performance based financing of universities - case study of Slovaika', Scientific Papers of the University of Pardubice, Series D, Faculty of Economics and Administration, Vol. 24, No. 41, pp. 169-180.

Tan, P., Wu, H., Li, P. and Xu, H. (2018) 'Teaching management system with applications of RFID and IoT technology', Education Sciences, Vol. 8, No. 1, pp. 1-13. http://dx.doi. org/10.3390/educsci8010026

Windham, D. M. (1988) 'Effectiveness indicators in the economic analysis of educational activities', International Journal of Educational Research, Vol. 12, No. 6, pp. 575-665. https://doi.org/10.1016/0883-0355(88)90011-0

Zygaitiene, B. and Buivydaite, E. (2017) 'Preparation of technology education teacher in Lithuania, Finland and Great Britain', 10th International Scintific Conference on Rula Environment, Education and Personality (REEP), Jelgava, pp. 408-415. 